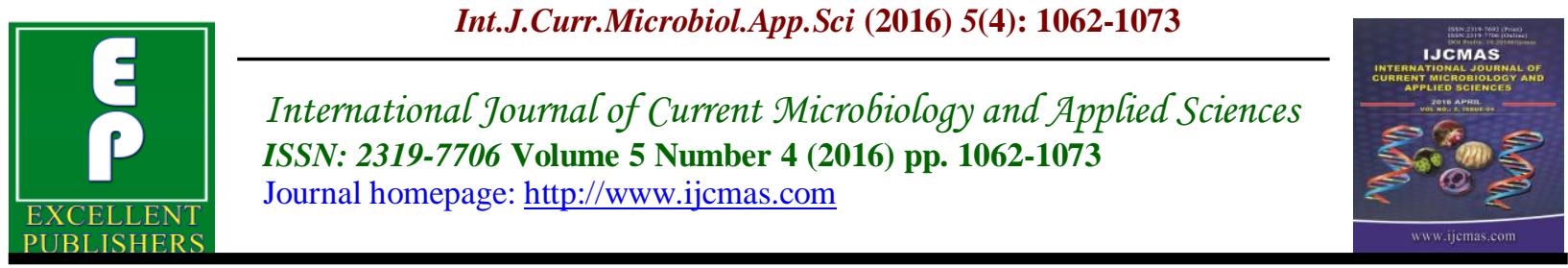

Original Research Article

http://dx.doi.org/10.20546/ijcmas.2016.504.121

\title{
The Influence of Pterocladia capillacea Extract on Growth and Antioxidant System of Cicer arietinum
}

\author{
Hamed M. El-Shora*, Shaaban-Dessouki, S.A. and Shaimaa E. El-Shafeey \\ Botany Department, Faculty of Science, Mansoura University, Egypt \\ *Corresponding author
}

\begin{tabular}{|c|c|}
\hline & A B S T R A C T \\
\hline Keywords & \multirow{9}{*}{$\begin{array}{l}\text { The chickpea, Cicer arietinum L. (Family: Fabaceae), is one of the most important } \\
\text { legume crop in the world because it has high nutritional value due to high protein } \\
\text { content and dietary fiber. Seaweeds are marine algae and they are rich source of } \\
\text { highly bioactive secondary metabolites. Therefore, chickpea seedlings were treated } \\
\text { with Pterocladia capillacea (S.G. Gmelin) Bornet (Rhodophyta) extract to find out } \\
\text { whether this extract can affect growth and defense system of chickpea. The root } \\
\text { length, shoot length, number of lateral roots and number of lateral shoots increased } \\
\text { under treatment with different algal extracts. The non-antioxidant compounds } \\
\text { including reduced glutathione (GSH), ascorbate, and proline of chickpea seedlings } \\
\text { increased under the treatment. Also, the activities of antioxidant enzymes } \\
\text { superoxide dismutase (EC: } 1.15 .1 .1 \text { ), catalase (EC: 1.11.16) and ascorbate } \\
\text { peroxidase (EC: } 1.11 .1 .11) \text { increased with different rates. It was observed that the } \\
\text { total protein and total carbohydrate contents of Cicer seedlings increased. The rate } \\
\text { of increase in the antioxidant system was dependent on extract concentration. }\end{array}$} \\
\hline & \\
\hline Extract, & \\
\hline & \\
\hline Antioxidant & \\
\hline Article Info & \\
\hline & \\
\hline & \\
\hline & \\
\hline
\end{tabular}

\section{Introduction}

Seaweeds are important marine resources and used as animal feed, human food, and raw materials for several industries (Anisimov et al., 2013; Kolanjinathan et al., 2014).

Seaweeds contain various vitamins, minerals, proteins, trace elements, iodine, bromine and bioactive substances. They are alsoa source of many useful products in medicines (Raghukumar, 2011).

Seaweed extracts are used as fertilizers in the ecological farming (Zhang and Ervin, 2007; Kumari et al., 2011). Also, they are applied as soil amendment (Gandhlyappan and Perumal, 2001), plant disease management and in pests control (Jayaraj et al., 2008).

Seaweeds are exposed to a combination of oxygen and light and this leads to the production of free radicals (Zubia et al., 2007). Seaweeds protect themselves against free radicals by developing antioxidant defense system, including enzymatic and non-enzymatic (Halliwell and Gutteridge, 2001; Burtin, 2003; Ashraf and Foolad, 2007; Piotrowska-Niczyporuk and Bajguz, 2013). 
Chickpea (Cicer arietinum L.) is cultivated throughout the world (Segev et al., 2011). Chickpeais characterized by its nutritional value because of high protein content and dietary fiber. It has appreciable antioxidant activity (Heiras-Palazuelos et al., 2013). Chickpea has been used for treating many diseases astonic to hair, abortifacient, diarrhea, useful in cold pains, used in indigestion, anti- leukemic and dysentery (Ahmed et al., 2009).

Thus, the present paper aimed to investigate the influence of Pterocladia capillace a extract on the growth criteria and the antioxidant system of Cicer arietinum.

\section{Materials and Methods}

\section{Collection of Algal Material}

The seaweed was collected from the submerged rocks on the coastal of Abu-Qir Alexandria - North Egypt during October 2014, representing autumn. It was chosen because it was present in large quantities in the collection sites. Samples were brought to laboratory in plastic bags containing sea water for preventing evaporation.

\section{Preparation of Algal Samples}

Seaweed was cleaned up from epiphytes and extraneous by running tap water and rinsed several times in distilled water. The samples were then spread and allowed to dry in air at room temperature. The air dried samples were ground and stored at room temperature (Abu El-Wafa, 2005).The algal sample was identifiedfollowing Aleem (1993).It was Pterocladia capillacea (S.G. Gmelin) Bornet (Rhodophyta).

\section{Preparation of Algal Extract}

The aqueous extract was prepared as described by El-Shora et al. (2015d) from dried powder of Pterocladia capillacea.
Five grams of powder was soaked in $100 \mathrm{ml}$ of distilled $\mathrm{H} 2 \mathrm{O}$ for $24 \mathrm{hr}$ at room temperature, and filtered through filter paper to obtain $5 \% \mathrm{w} / \mathrm{v}$. The filtrate was then centrifuged at $3500 \mathrm{rpm}$ for $25 \mathrm{~min}$ and the resultant supernatant was used for chemical tests.

\section{Plant Materials}

The experimental plant used in this investigation was Cicer arietinum L (chickpea, family Fabaceae). The pure strain of seeds was obtained from Egyptian Ministry of Agriculture.

\section{Seeds Sterilization}

Growth of the tested plants was carried out according to the method of El-Shoraand Abd El-Gawad, 2014a).Chickpea seeds were surface sterilized in $0.5 \%(\mathrm{v} / \mathrm{v})$ sodium hypochloride for $15 \mathrm{~min}$ and then rinsed several times with distilled water.

\section{Treatment with Algal Extract}

The sterilized seeds were placed in $90 \mathrm{~cm}$ sterile Petri dishes over Whatman No. 1 filter paper. The seeds were allowed to germinate in the dark at $25 \pm 1{ }^{\circ} \mathrm{C}$ for 5 days. The 5-day old seedlings with uniform length were divided into two groups each contain 20 seedlings. Each group was transferred to plastic pot and supplemented with Hoagland's nutrient solution (Hoagland and Arnon, 1950) for 7 days. After 7 daysgroup 1 was treated with aqueous extract ofPterocladia capillacea (red alga)and group 2 was left without treatment (control). All the pots were put in a growth chamber under the following conditions: a 16-h light / 8-h darks photoperiod, $22 \pm 1$ ${ }^{\circ} \mathrm{C}$, day/night temperature, and $350 \mu \mathrm{mol} \mathrm{m} 2$ s-1 photon flux density. The solution was aerated continuously with an air pump and 
renewed every 24 h. All plants were harvested after 7 days of treatment for analysis.

\section{Estimation of Growth Parameters}

Plant growth was measured on the basis of: shoot length $(\mathrm{cm})$, root length $(\mathrm{cm})$, number of lateral roots and number of leaves.

\section{Total Glutathione}

GSH was estimated according El-Shora and Abd El-Gawad (2014b).The reaction mixture contained $1 \mathrm{ml}$ of $150 \mathrm{mM} \mathrm{Na}$ phosphate buffer ( $\mathrm{pH} 7.5$ ) with $0.2 \mathrm{ml}$ of $10 \mathrm{mM}$ 5,5-dithio-bis-(2-nitrobenzoic acid) (DTNB), $0.2 \mathrm{ml}$ of $10 \mathrm{mMEDTA}, 0.1 \mathrm{ml}$ of $5 \mathrm{mM}$ NADPH and $0.5 \mathrm{ml}$ glutathione reductase (GR). The change in absorbance was measured at 412 nm spectrophotometrically. For determination of GSSG content, 2-vinylpyridine was added to the extract and GSH content was calculated by subtracting the GSSG content from the total glutathione content.

\section{Proline Content}

The proline content was determined using the acid ninhydrin according to the method of Bates et al. (1973). A sample (5gm) of the leaf tissue was homogenized with $5 \mathrm{ml}$ of $3 \% \quad(\mathrm{w} / \mathrm{v})$ sulfosalicylic acidand the resulting homogenate was filtered through Whatman No. 1 filter paper. Two $\mathrm{ml}$ of the filtered extract was mixed with $2 \mathrm{ml}$ acid ninhydrin and $2 \mathrm{ml}$ of glacial acetic acid. The reaction mixture was incubated for $1 \mathrm{~h}$ in a boiling water bath and the reaction was terminated in an ice bath. Toluene $(4 \mathrm{ml})$ was added to the reaction mixture and the organic phase was extracted, in which a toluene soluble reddish chromophore was obtained, which was read spectrophotometrically at $520 \mathrm{~nm}$ using toluene as blank by UV-visible spectrophotometer.

\section{Preparation of Enzyme Extract}

Fresh leaves (2gm) were homogenized with amortar and pestle under chilled conditions with $50 \mathrm{mM}$ phosphate buffer ( $\mathrm{pH} 7.0$ ) containing $1 \%$ polyvinylpyrrolidone. The homogenate was filtered through muslin cloth and centrifuged at $6000 \mathrm{~g}$ for $10 \mathrm{~min}$ at $4 \mathrm{oC}$. The resulting supernatant was used for assaying the antioxidant enzymes including superoxide dismutase, catalase and ascorbate peroxidase.

\section{Assay of Antioxidant Enzymes}

\section{Superoxide Dismutase (SOD)}

Superoxide dismutase (SOD, EC 1.15.1.1) activity was determined by the method of Beauchamp and Fridovich (1971)through measuring the photo reduction of nitroblue tetrazolium (NBT) at $650 \mathrm{~nm}$. The reaction mixture $(3 \mathrm{ml})$ contained $50 \mathrm{mM}$ sodium phosphate buffer (pH 7.8), $75 \mu \mathrm{M}$ NBT, $13 \mathrm{mM}$ methionine, $2 \mathrm{mM}$ riboflavin, $10 \mu \mathrm{M}$ EDTAand enzyme extract $(100 \mu \mathrm{l})$. The reaction was started by placing the tubes below two 15-W fluorescent lamps for $10 \mathrm{~min}$ and then stopped by switching off the light. The absorbance was measured spectrophotometrically at $650 \mathrm{~nm}$. One unit of SOD was defined as the quantity of enzyme that produced $5 \%$ inhibition of NBT reaction under assay conditions.

\section{Catalase (CAT)}

The activity of catalase enzyme was determined according to the method of Aebi (1984). The assay mixture $(3 \mathrm{ml})$ contained $100 \mu \mathrm{H} 2 \mathrm{O} 2$ (100 mM), $100 \mu \mathrm{l}$ enzyme extract and $2.8 \mathrm{ml} 50 \mathrm{mM}$ phosphate buffer with $2 \mathrm{mM}$ EDTA (pH 7.0). CAT activity 
was assayed by measuring the decrease in the absorbance at $240 \mathrm{~nm}$.

\section{Ascorbate Peroxidase (APX)}

The activity of ascorbate peroxidase was assayed according to the method of Nakano and Asada (1981). The assay mediumcontained50 $\mathrm{mM}$ sodium phosphate buffer ( $\mathrm{pH} 7.0$ ), $0.1 \mathrm{mM} \mathrm{H} 2 \mathrm{O} 2,0.5 \mathrm{mM}$ ascorbic acid, $0.1 \mathrm{mM}$ EDTA, and $0.2 \mathrm{ml}$ enzyme extract. The decrease in absorbance was measured at $290 \mathrm{~nm}$ for $1 \mathrm{~min}$.

\section{Estimation of Protein}

The soluble protein content was determined as described by Bradford (1976). The concentration of protein was calculated from standard curve using bovine serum albumin (BSA) as standard.

All the data in the present study are expressed as mean \pm SE obtained from three measurements.

\section{Results and Discussion}

Treatment of Cicer seedlings with Pterocladia extract resulted in an enhancement of root length, shoot length(Fig. 1),number of lateral roots and number of leaves(Fig. 2). In support, Erulan et al. (2009) reported that seaweed liquid fertilizer enhanced the growth parameters including root length, shoot length, leaf area, fresh weight and dry weight.

Crouch et al. (1990) observed that seaweed extracts improved the nutrient uptake by roots with improved water and nutrient efficiency (Kumari et al., 2011). It was also reported that seaweed products promoted root growth and plant development (Jeannin et al., 1991).Seaweed extracts are important source of plant nutrition for sustainable agriculture production (Khan et al., 2009) as they contain vitamins, various trace elements as well as amino acids benefiting the plant growth and development.

Seaweed extracts are biostimulant mainly due to the presence of plant hormones in seaweed extracts including: cytokinins, auxins, abscisic acid, gibberellins, salicylic acid, ethylene and some other bioactive compounds such as betaines (El-Miniawy et al., 2014).

Abdel Aziz et al. (2011) found that seaweeds extract contain a high cytokine in content, which could be responsible for plant growth. Also, they reported that seaweeds extracts contain active chemical constituents which can regulate shoot elongation, cell division, protein synthesis, leaf aging and senescence, enzyme formation and fruit set. In addition, cytokinins in seaweed include trans-zeatin, trans-zeatin riboside dihydro derivatives (Stirk and Van Staden, 1997). These cytokinins play essential role in transport of nutrients and inhibit aging (Lewak and Kopcewicz, 2009) and theyareinvolved in regulation of cell division.

Gibberellins initiate seed germination as well as growth regulation and gibberellic acid is the most important growth stimulating substance forcell division and cell elongation(Mahmoody and Noori, 2014).

Abscisic acid as an auxin participates in regulation of seed germination. Seaweed extract increased the defense system of chickpea. Similar results were recorded for Cajanus Cajanby Padina extract (Mohan et al., 1994).

Yokoya et al. (2010) and Devi and Paul (2014) reported that phytohormones are found in seaweed extracts in various concentrations and they can stimulate the growth or abscission and senescence 
according to their concentration.

Also, Ramya et al., (2010) reported that seaweed extracts contain glycine betaine which improved the growth yield of Cyamopsistetra gonolaba. Glycine betaine acts as osmoregulator, act as active oxygen scavenger and provide protein stabilization (Ashraf and Foolad, 2007; Mohamood et al., 2009).

Glutathione exists in two forms reduced glutathione (GSH) and oxidized glutathione
(GSSG). Reduced glutathione (GSH) content increased but the oxidized glutathione (GSSG) decreased in Cicer leaves (Fig. 3) after treatment with pterocladia extract. GSH is abundant thiol in eukaryotes including plants. The reduction potential of glutathione depends on the intercellular GSH/GSSG ratio. Changes in the redox ratio of glutathione mainly depend on the total GSH concentration, GSH biosynthesis, GSH catabolism and $\mathrm{pH}$ (Mullineaux and Rausch, 2005).

Fig.1 Root length and Shoot Length of $C$. arietinum treated with $P$. capillacea Extract

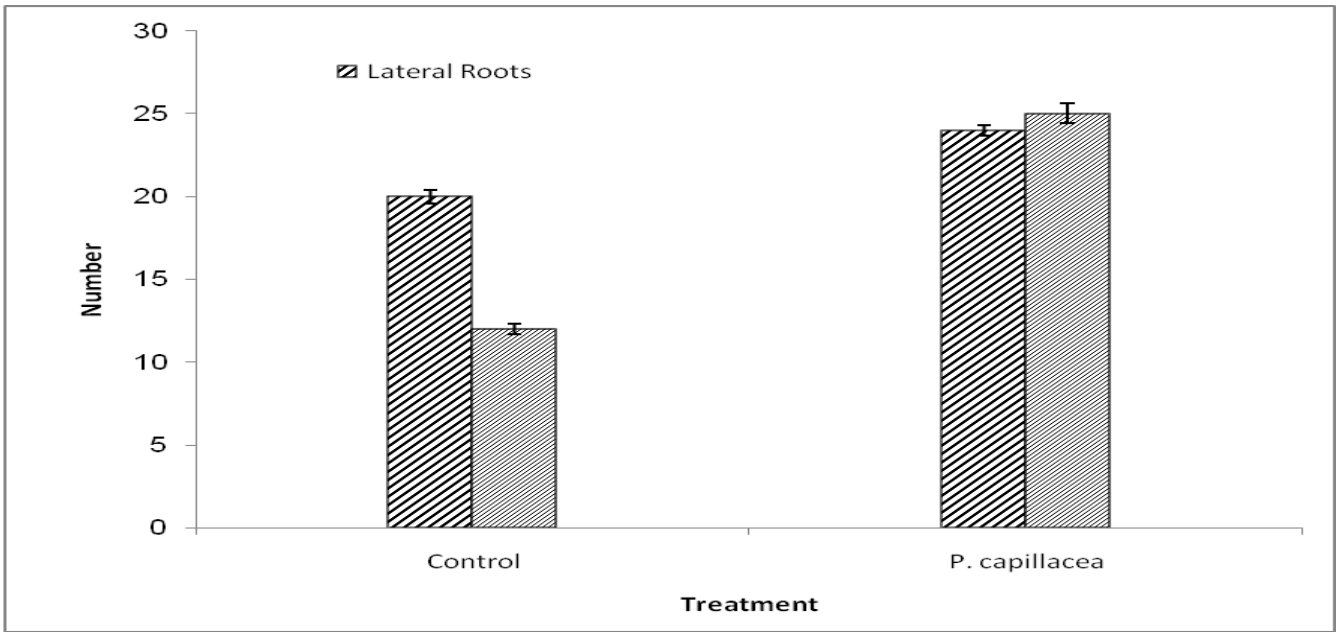

Fig.2 Number of Lateral Roots and Number of Leaves of $C$. arietinum treated with $P$. capillacea Extract

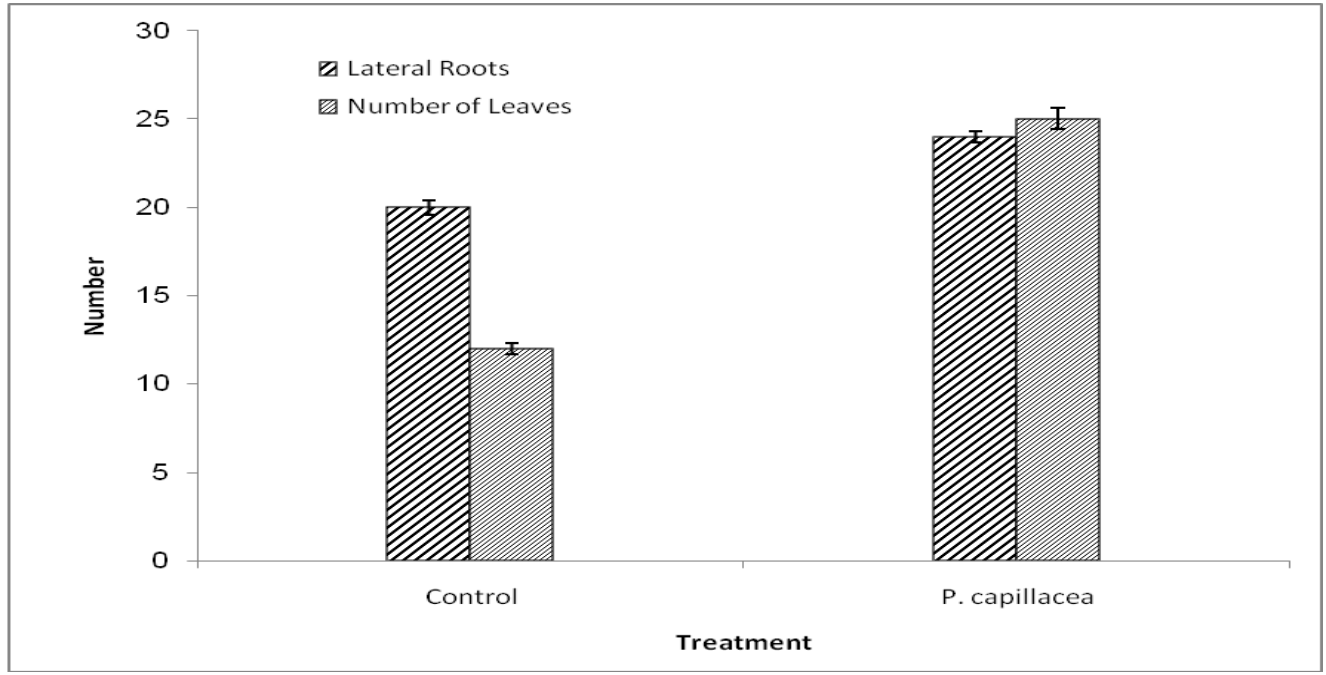


Fig.3 Effect of $P$. capillacea Extract on GSH and GSSG in C. arietinum

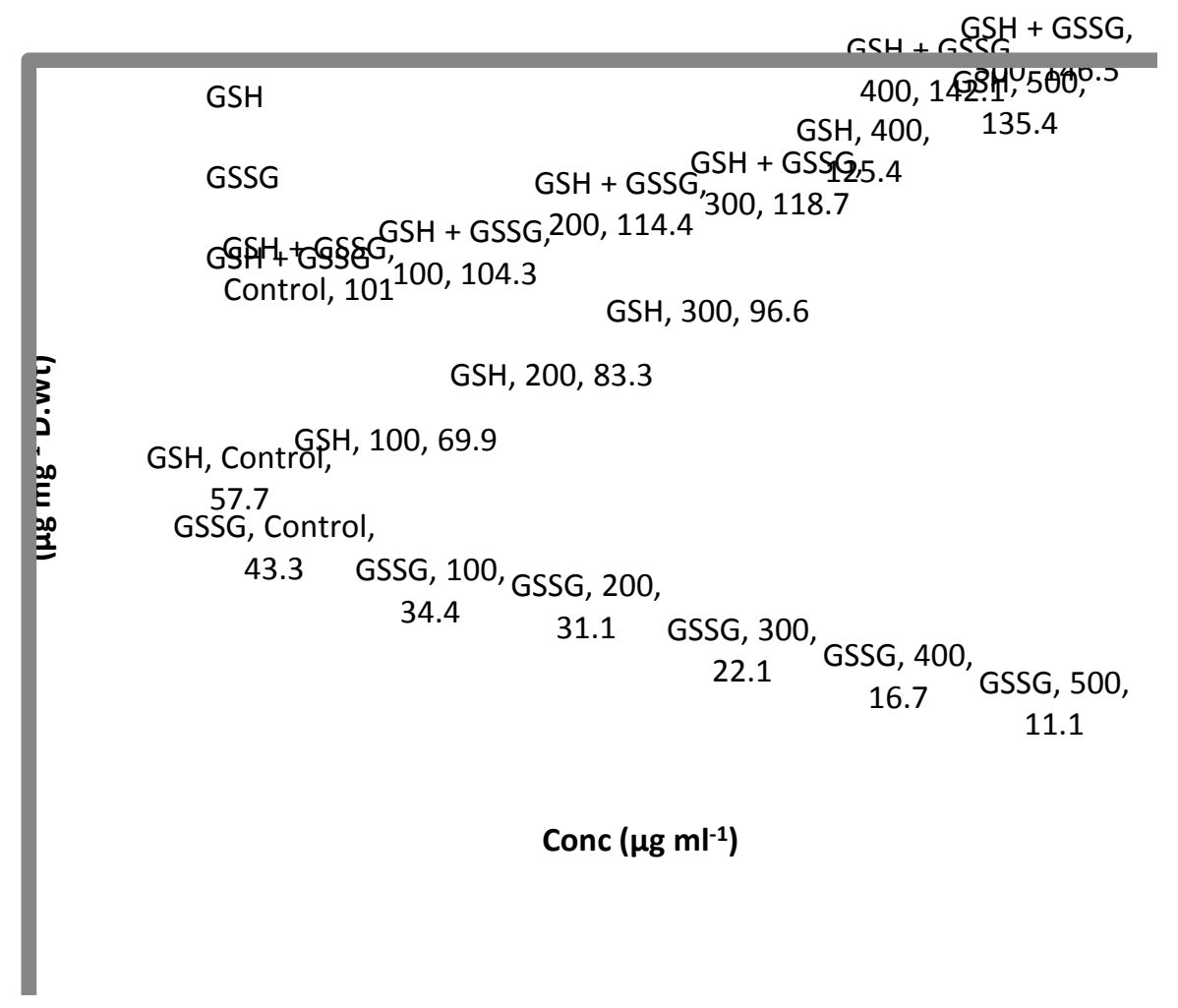

Fig.4 Effect of $P$. capillaca Extract on Ascorbate Content in C. arietinum

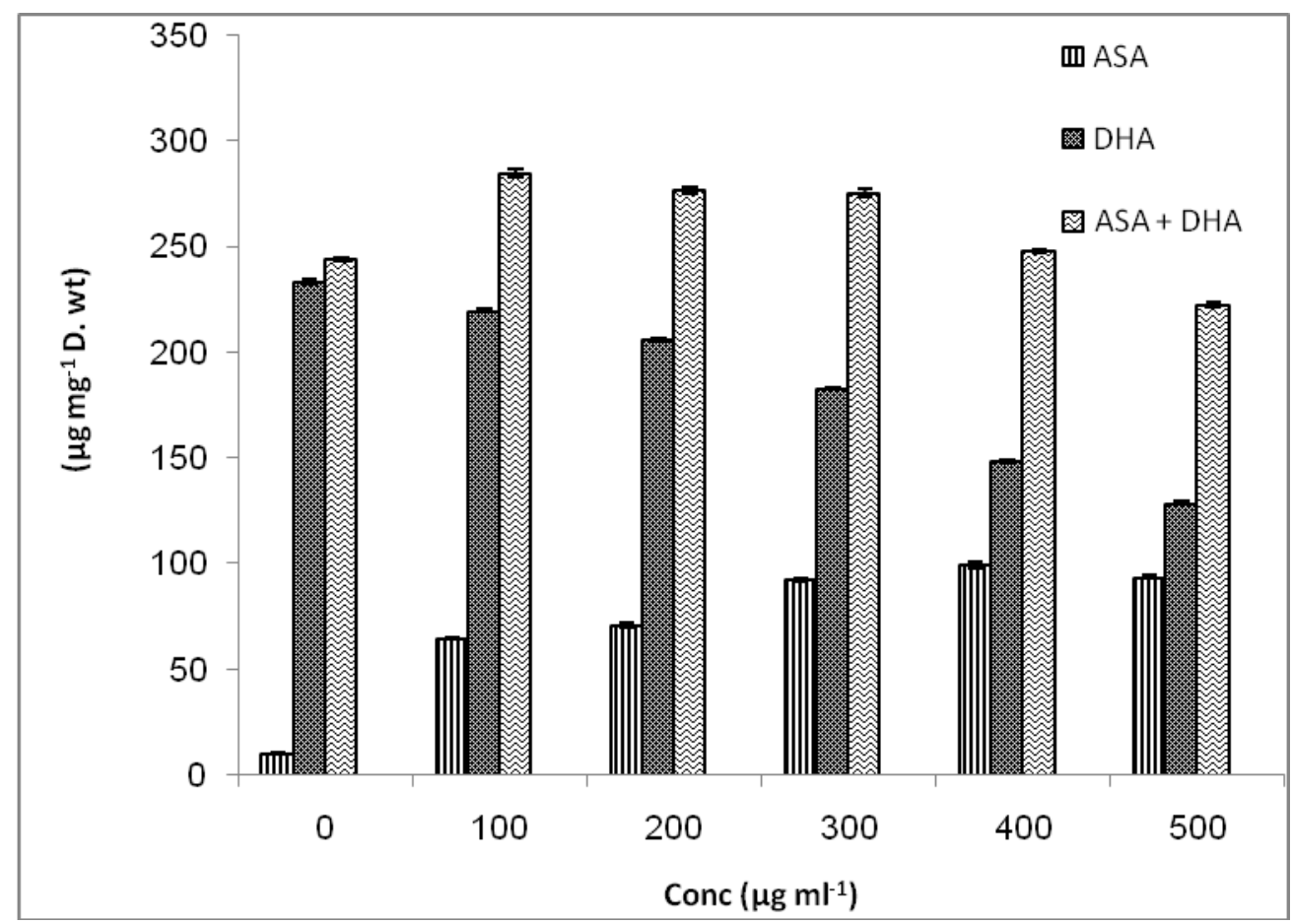


Fig.5 Effect of P.capillacea Extract on Proline Content in C. arietinum

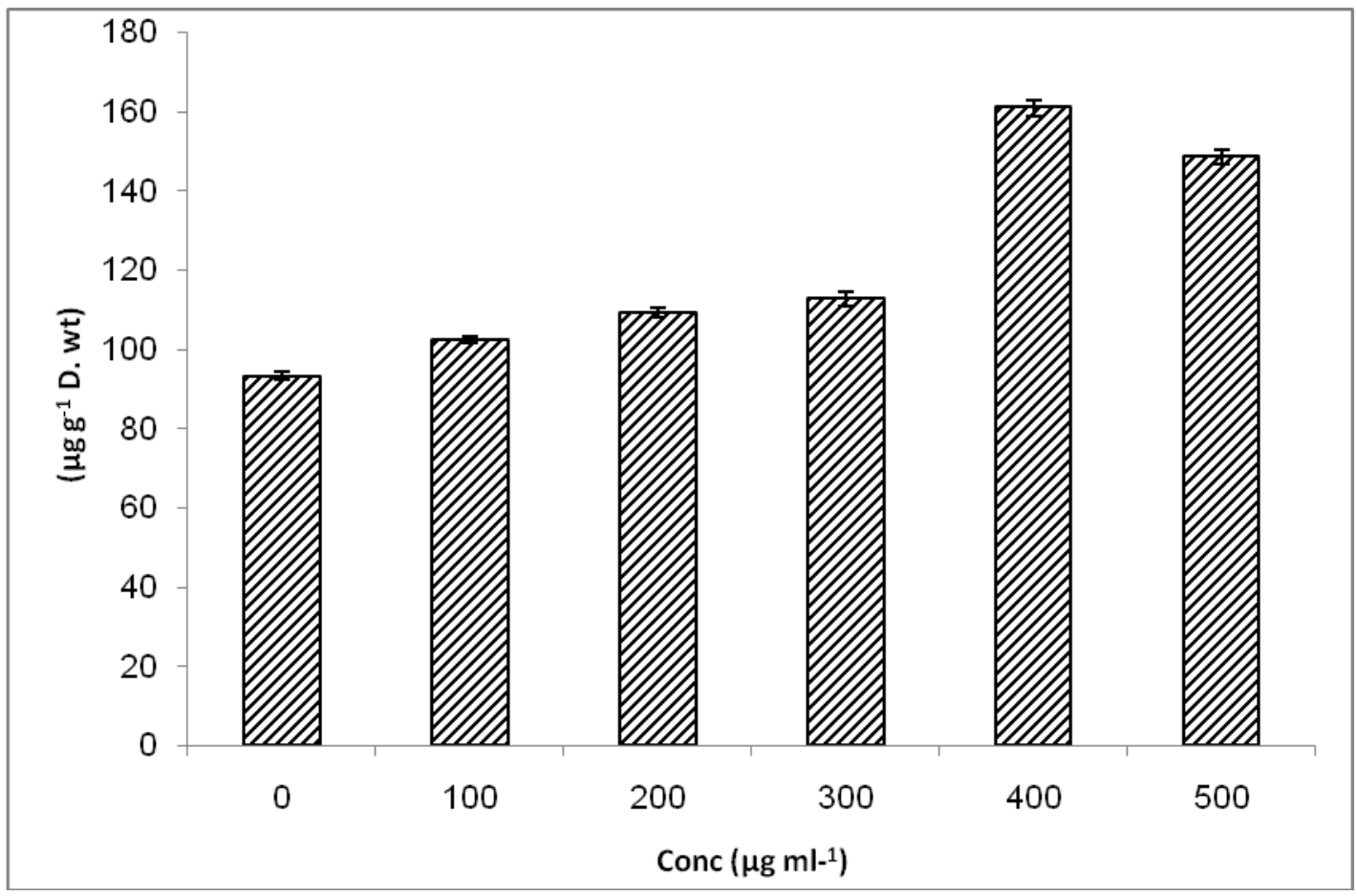

Fig.6 Effect of $P$. capillacea Extract on the Activities of Antioxidant Enzymes in C. arietinum

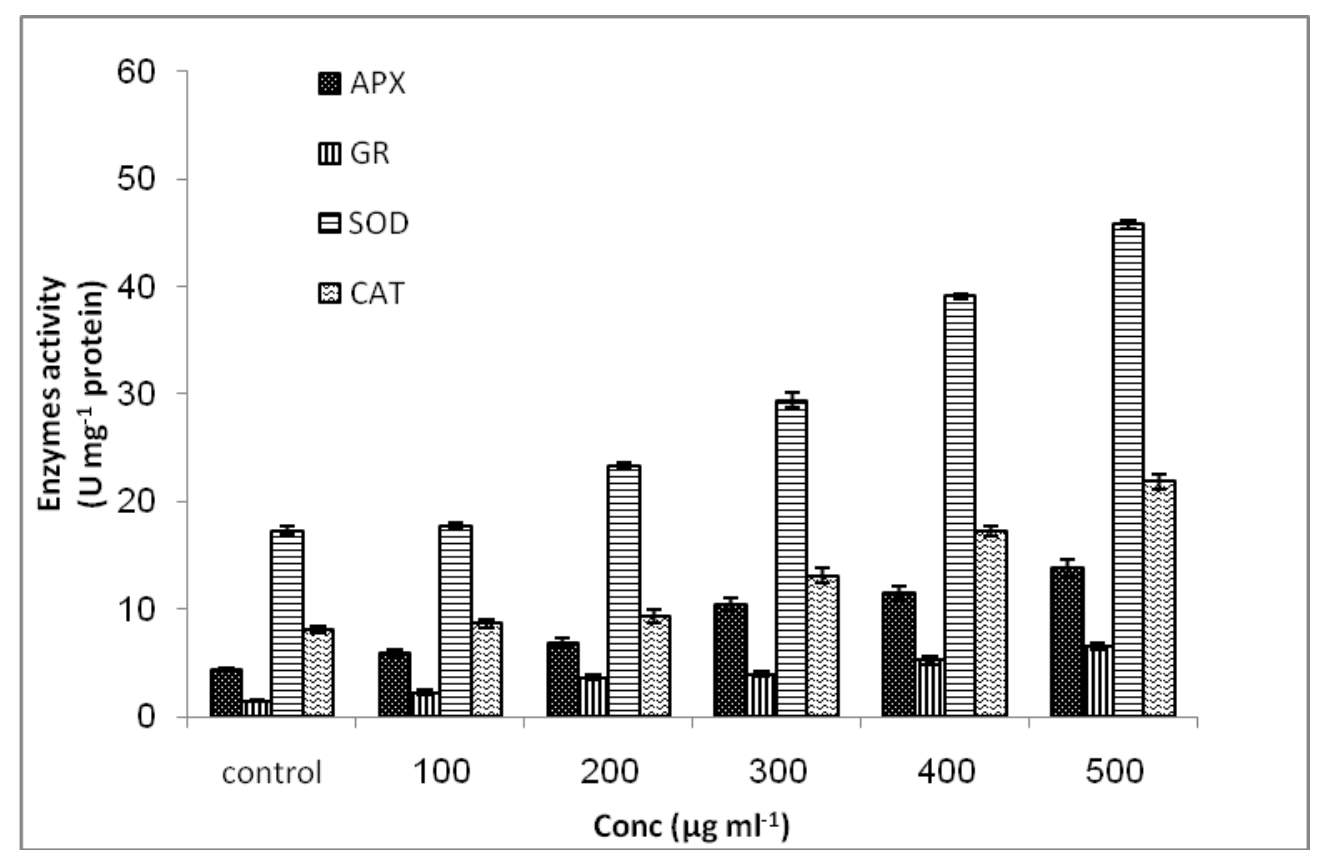


Fig.7 Effect of $P$. capillacea Extract on Total Protein Content in C. arietinum

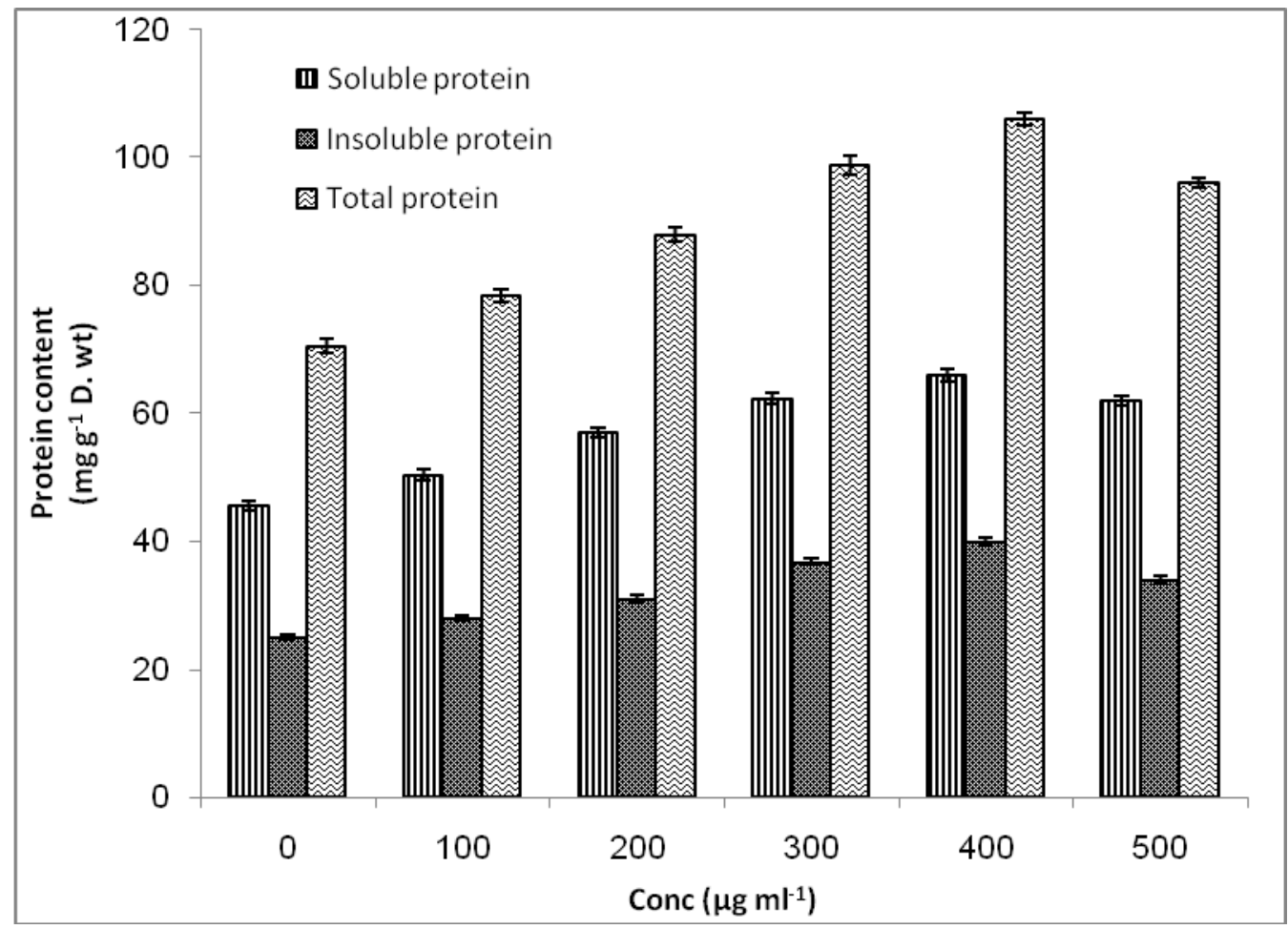

Fig.8 Effect of $P$. capillacea Extract on Carbohydrate Content in C. arietinum

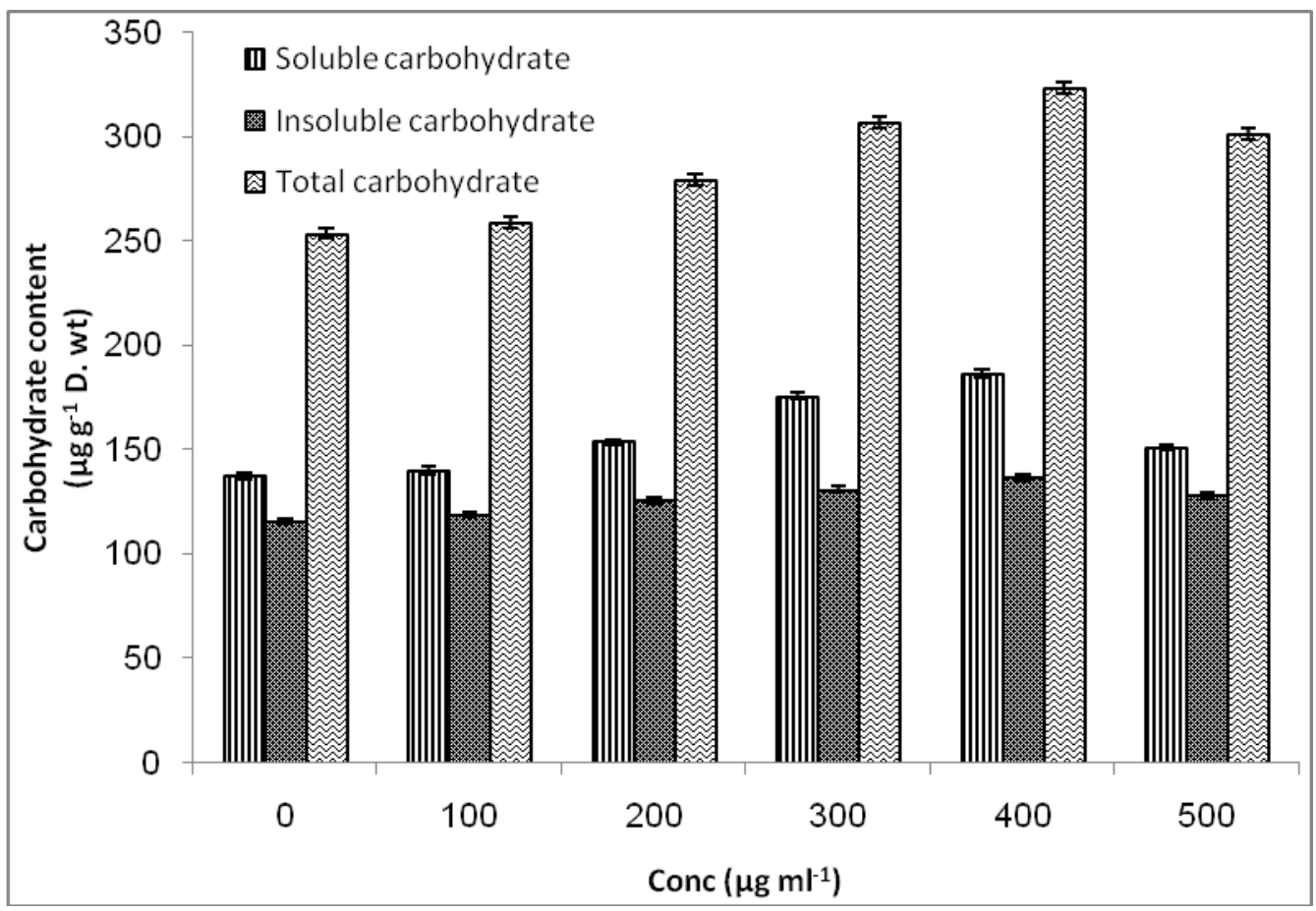


The increase in GSH by seaweed extracts may be attributed to the role of auxins of seaweed extract in reducing of lipid peroxidation by stimulation of ascorbate and glutathione thus regulating the homeostasis of reactive oxygen species (PiotrowskaNiczyporuk and Bajguz, 2013).

Ascorbateis one of the most important nonenzymatic antioxidant (El-Shora et al., 2015d) increased with increasing concentration of seaweed extract (Fig 4). The ratio of ASA/DHA is considered as an important indicator for the degree of oxidative stress and the redox state of the cell (Asada, 1994).

Treatment of Cicer seedlings with seaweeds induced proline content (Fig. 5). Rhodes and Hanson (1993) observed an increase in proline concentration after seaweed treatment suggesting that seaweed extract could be applied to stressed-plants to gain tolerance against stress. Proline acts as a free radical scavenger and important in overcoming stress than acting asosmolyte. Proline accumulation in Cicer leaves by seaweed extract may be due to activation of proline biosynthesis and inactivation of proline degradation. Proline and betaines are suggested to play a pivotal role in cytoplasmic adjustment in response to osmotic stress.

Treatment of Cicer seedlings with seaweed extract increased the activities of tested antioxidant enzymes (Fig. 6) including SOD, CAT, and APX. SOD is the first line of defense against ROS that convert $\mathrm{O} .2$ to $\mathrm{O} 2$ and $\mathrm{H} 2 \mathrm{O} 2$ (El-Shora, 2003; Nasir et al., 2015). CAT and APX convert $\mathrm{H} 2 \mathrm{O} 2$ to $\mathrm{O} 2$ and H2O (El-Shora et al., 2004). CAT activity was higher than APX revealing that removing $\mathrm{H} 2 \mathrm{O} 2$ occurs mainly by CAT. The increase in the enzymes activities may be due to the effect of auxins in seaweed extract which may induce the antioxidant enzymes to scavenge ROS (PiotrowskaNiczyporuk and Bajguz, 2013).

The soluble protein (Fig. 7) increased under treatment with Pterocladia extract. This increase could be attributed to retardation of proteolysis, the increase in protein synthesis, availability of amino acids and activation of enzymes of protein synthesis. The increase in protein content of Cicer leaves under treatment with seaweed extract suggests that Pterocladia extract may have substances responsible for such increase. It has been reported that seaweeds extracts have amino acids and zinc. Zinc is present in various enzymes of all six classes of enzymes (Broadley et al., 2012).

The soluble carbohydrate content increased (Fig. 8) after treatment with Pterocladia extract. Sridhar and Rengasamy (2010) reported that the inducible effects of seaweed application are correlated with the increase of total soluble carbohydrate in Tageteserecta. Thus, the increase of carbohydrates in the present results could be due to the improvement effect of seaweed extract on photosynthetic efficiency and this might be related to cytokinins, auxins, macro- and micro-nutrients in the seaweed extracts (Abdel Aziz et al., 2011).

In conclusion, the present results showthe beneficial effect of seaweed extract application on the growth and antioxidant system of chickpeaas crop plant. The exhibited effects are a result of many components in the extracts that may works synergistically at different concentrations, although the mode of action still remains unknown.

\section{References}

Abd El Aziz, N.G., Mahgoub, H.M., Siam, S.H. 2011. Growth flowering and chemical constituents performance of 
Amaranthus tricolor plants as influence by seaweed (Ascophyllum nodosum) extract application under salt stress conditions. J. Appl. Sci. Res., 11: 14721484.

Abu El-Wafa, G.S. 2005. Studies on the Biological Activities SomeSpecies of Egyptian Marine Algae. MSc. Thesis. Botany Dept., Faculty of Sci., Mansoura Univ.Egypt.

Aebi, H. 1984. Catalase. In: L. Packer(Ed), Methods in Enzymology. Academic Press, Orlando. 105: 121-126.

Ahmed, M., Qureshi, R., Arshad, M., Khan1, M.A., Zafar, M. 2009. Traditional herbal remediates used for the treatment of diabetes from district attack (Pakistan). Pakistan J. Bot., 41: 27772782.

Aleem, A.A. 1978. Contributions to the study of the marine algae of the Red Sea. The algae in the neighborhood of AlGhardaqa, Egypt. Bull. Fac. Sci. K.A.U. Jeddah, 2: 99-118.

Anisimov, M.M., Skriptsova, V.A., Chaikina, L.E., Klykov, G.A. 2013. Effect of water extracts of seaweeds on the growth of seedling roots of buckwheat (Fagopyrumes culentum Moench). IJRR As.,16: 2-16.

Asada, K. 1994. Production and action of active oxygen species in photosynthetic tissues. In: Causes of photo-oxidative stress and amelioration of defense system in plants (Foyer $\mathrm{CH}$, Mulineaux PM, EDs). CRC Press, Boca Raton. Ann Arbor. London. Tokyo, pp 77-100.

Ashraf, M., Foolad, M.R. 2007. Roles of glycine betaines and proline in improving plant abiotic stress resistance. Environ. Expert. Bot., 59: 206-216.

Bates, L.S., Woldren, R.P., Teare, I.D. 1973. Rapid determination of free proline for water stress studies. Plant Soil, 39: 205-208.

Beauchamp, C.O., Fridovich, I. 1971. Superoxide dismutase: Improved assays and an assay applicable to acrylamide gel. Anal. Biochem., 44: 275-287.

Bradford, M.M. 1976. Rapid and sensitive method for the quantitation of microgram quantities of protein utilizing the principle of protein dye binding. Analyt. Biochem., 72: 248-254.

Broadley, M., Brown, P., Cakmak, I., Rengel, Z., Zhao, F. 2012. Chapter 7 - Function of Nutrients: Micronutrients. In: Marschner, P. ed, Marschner's Mineral Nutrition of Higher Plants (Third Edition). Academic Press, San Diego, pp: 191-248.

Burtin, P. 2003. Nutritional value of seaweeds. Elect. J. Environ. Agric. Food Chem., 2: 498-503.

Crouch, I.J., Beckett, R.P., Van Staden, J. 1990. Effect of seaweed concentrate on the growth and mineral nutrition of nutrient stressed lettuce. J. Appl. Phycol., 2: 269-272.

Devi, S.S., Paul, P.J. 2014. Influence of seaweed liquid fertilizer of Gracilaria dura (AG.) J.AG (red seaweed) on Vignaradiana (L.) R. Wilczek, in Thoothukudi, Tamil Nadu, India. World J. Pharmac., 3: 968-978.

El-Miniawy, S.M., Ragab, M.E., Yousef, S.M., Metwally, A.A. 2014. Influence of foliar spraying of seaweed extract on growth, yield, and quality of strawberry plants. J. Appl. Sci. Res., 102: 88-94.

El-Shora, H.M., Essam, M., Youssef, M.M. 2004. The toxic effects of cadmium and copper on the antioxidative enzymes and lipid peroxidation in marrow roots. Mans. Univ. Sci. Bull., Vol. 30: 128140.

El-Shora, H.M. 2003. Activities of ant oxidative enzymes and senescence in detached Cucurbita pepo leaves under $\mathrm{Cu}$ and oxidative stress by $\mathrm{H} 2 \mathrm{O} 2$. Moscow Univ. Chem. Bull., Vol. 44: 66-71.

El-Shora, H.M., Abd El-Gawad, A. 2014a. Evaluation of allelopathic potential of Rumex dentatus root extract and 
allelochemicals on Cicer arietinum. J. Stress Physiol. Biochem., 10: 167-180.

El-Shora, H.M., Abd El-Gawad, A. 2014b. Environmental toxicity of arsenic on lupine (Lupinustermis L.) as C3 crop plant and possible alleviation. Int. J. Agri. Crop Sci., 7: 687-692.

El-Shora, H.M., El-Farrash, A.H., Kamal, H., Abdelrazek, A. 2015b. Positive role of UV radiation in enhancing secondary metabolites production in Fenugreek leaves. Int. J. Sci. Res., 5: 536-543.

El-Shora, H.M., El-Farrash, A.H., Kamal, H., Abdelrazek, A. 2015d. Influence of gamma radiation on the antioxidant capability of Fenugreek. Res. J. Pharm. Biolog. Chem. Sci., 6: 574- 582.

Erulan, V., Thirumaran, G., Soundarapandian, P., Ananthan, G. 2009. Studies on the effect of Sargassumpolycystum extract on the growth and biochemical composition of Cajanuscajan (L.) Mill sp, American-Eurasian J. Agric. Environ. Sci., 6: 392-399.

Gandhlyappan, K., Perumal, P. 2001. Growth promoting effect of seaweed liquid fertilizer (Enteromorpha intestinalis) on the sesame crop plant, Seaweed Res. Util. 23: 23-25.

Halliwell, B., Gutteridge, J.M.C. 2001. Reactive species can be poisonous. In: Halliwell, B., and Gutteridge, J.M.C. (Eds) Free Radicals in Biology and Medicine. Oxford University Press, New York. 4: 440-487.

Heiras-Palazuelos, M.J., Ochoa-Lugo, M., Mora-Rochin, S., Gutierrez-Dorado, R., Milan-Carrillo, J., Garzon-Tiznado, J.A., Reyes-Moreno, C. 2013. Technological properties, antioxidant activity and total phenolic andflavonoid content of pigmented chickpeas (Cicer arietinum L). Cultivars. Int J. food Sci.Nutr., 64: 69-76.

Hoagland, D.R., Arnon, D.I. 1950. The waterculture method for growing plants without soil. Univ. of California. Agric. Exp. Stn. Circ., 347. Univ. of California, Berkeley, CA.
Jayaraj, J., Wan, A., Rahman, M., Punja, Z.K. 2008. Seaweeds extracts reduces foliar fungal disease on carrot, Crop Prot., 27: 1360-1366.

Jeannin, I., Lescure, J.C., Morot-Gaudry, J.F 1991. The Effects of aqueous seaweed sprays on the growth of maize. Bot. Mar., 34: 469-473.

Khan, W., Ravihankar, P., Alan, T.C., Donald, L.S., Yousef, P., Balakrishan, P. 2013. Ascophyllumnodosum extract and its organic fractions stimulate Rhizopium root nodulation and growth of Medicago sativa. Communications in Soil Science and Plant Analysis.

Khan, W., Rayirath, U.P., Subramanian, S., Jithesh, M.N., Rayorath, P., Hodges, D. M., Critchley, A. T., Craigie, J. S., Norrie, J., Prithiviraj, B. 2009. Seaweed extracts as biostimulants of plant growth and development. J. Plant Growth Regul., 28: 386-399.

Kolanjinathan, K., Ganesh, P., Saranraj, P. 2014. Pharmacological importance of seaweeds, World J. Fish and Marine Sci., 6: 1-15.

Kumari, R., Kaur, I., Bhatnagar, A.K. 2011. Effect of aqueous extract of Sargassum johnstonil on growth, yield and quality of Lycopersicones culentum Mill., J. Appl. Phycol., 23: 623-633.

Lewak, S., Kopcewicz, J. 2009. Fizjologiaros'lin. Wprowadzenie, Wydawnictwo Naukowe PWN, 3: 120122.

Mahmood, T., Ashraf, M., Shahabaz, M. 2009. Does exogenous application of glycinebetaine as a pre-sowing seed treatment improve growth and regulate some key physiological attributes in wheat plant grown under water deficit conditions. Pakistan J. Bot., 41: 129111302.

Mahmoody, M., Noori, M. 2014. Effect of gibberellic acid on growth and development plants and its relationship with abiotic stress. Int. J. Farm. Allied Sci., 3(6): 717-721. 
Mohan, V.R., Venkataraman, V.K., Murugewari, R., Muthuswami, S. 1994. Effect of crude and commercial seaweed extract on seed germination and seeding growth in Cajanuscajan L. Phykos, 33: 47-51.

Mullineaux, P.M., Rausch, T. 2005. Glutathione, photosynthesis and the redoxregulation of stress-responsive gene expression. Photos. Res., 86: 459474.

Nakano, Y., Asada, K. 1981. Hydrogen peroxide is scavenged by ascorbatespecific peroxidase in spinach chloroplasts. Plant Cell Physiol., 22: 867-880.

Nasir, K.M, Mobin, M., Abbas, Z.K. 2015. Variation in photosynthetic pigments, antioxidant enzymes and osmolyte accumulation in seaweeds of Red Sea. Int. J. Plant Biol., 3: 10-28.

Piotrowska-Niczyporuk, A., Bajguz, A. 2013. The effect of natural and synthetic auxins on the growth, metabolite content and antioxidant response of green alga Chlorella vulgaris. Plant Growth Regul., 73: 57-55.

Raghukumar, S. 2011. Marine biotechnology. An approach based on components, levels and players. Indian J. Geo Mar. Sci., 40: 609-619.

Ramya, S., Sivas, S.N., Vijayanand, N. 2010. Biofertilizer efficiency of brown and green algae on the growth biochemical and yield parameters of Cyamopsistetra gonolaba L. Rec. Res. Sci. Technol., 24: 45-52.
Rhodes, D., Hanson, A.D. 1993. Quaternaiy ammonium and tertiary sulfonium compounds in higher plants. Ann. Rev. Plant Physiol. Plant Mol. Biol., 44: 357-384.

Segev, A., Badani, H., Galili, L., Hovav, R., Kapulnik, Y., Shomer, I. 2011. Totalphenolic content and antioxidant activity of chickpea (Cicer arietinum L.) as affected bysoaking and cooking conditions. Food Nutr. Sci., 2: 724-730.

Sridhar, S., Rengasamy, R. 2010. Effect of seaweed liquid fertilizer on the growth, biochemical constituents and yield of Tageteserecta, under field trial. $J$. Phycol., 25: 61-68.

Stirk, W.A., Van Staden, J. 1997. Isolation and identification of cytokinins in a new commercial seaweed product made from Fucus serratus L. J. Appl. Phycol., 9: 327-330.

Yokoya, N.S., Stirk, W.A., Van Staden, J., Nova, K.O., Tureckova, V., Pencik, A., Strand, M. 2010. Endogenous cytokinins, auxins and abscisic acid in red algae from Brazil. Phycol., 46: 1198-1205.

Zhang, X., Ervin, E.H. 2007. Impact of seaweed extract-based cytokinins and zeatin riboside on creeping bentgrass heat tolerance, Crop.Sci., 48: 364-370.

Zubia, M., Robledo, D., Pelegrin, Y.F. 2007. Antioxidant activities in tropical marine macroalgae from the Yucaton Peninsula, Mexico, J. Appl. Phycol., 19: 449-458.

\section{How to cite this article:}

Hamed M. El-Shora, Shaaban-Dessouki, S.A. and Shaimaa E. El-Shafeey. 2016. The Influence of Pterocladia capillacea Extract on Growth and Antioxidant System of Cicer arietinum. Int.J.Curr.Microbiol.App.Sci.5(4): 1062-1073. doi: http://dx.doi.org/10.20546/ijcmas.2016.504.121 